\title{
Identificación molecular del virus ToYVSV asociado al cultivo del tomate en el valle de Azapa (Arica, Chile)
}

\author{
Molecular identification of ToYVSV virus associated to tomato crop \\ in the valle de Azapa (Arica, Chile) \\ Wilson Huanca-Mamani $^{1 *}$ y Diana Trejo-Saavedra ${ }^{2}$
}

\section{RESUMEN}

En este trabajo se identifica y reporta parte de la secuencia del componente A de un begomovirus que infecta al cultivo del tomate en el valle de Azapa (Arica, Chile). El análisis filogenético de dicha secuencia mostró una identidad sobre el $88 \%$ con aislados de Tomato yellow vein streak virus (ToYVSV) colectados en Argentina y Brasil.

Palabras clave: tomate, virus, ToYVSV, Arica, Chile.

\begin{abstract}
In this work we report the component-A partial sequence identification from a begomovirus that infect tomato crop in the Azapa valley (Arica, Chile). Phylogenetics analysis from this sequence shows a identity value over $88 \%$ with Tomato yellow vein streak virus (ToYVSV) strain collected in Argentina and Brasil.

Key words: tomato, virus, ToYVSV, Arica, Chile.
\end{abstract}

\section{Introducción}

Los begomovirus son un importante grupo de virus de plantas que infectan al cultivo del tomate, son transmitidos por la mosquita blanca Bemisia tabaci (biotipo B) y de acuerdo a su filogenia y a la organización de su genoma se clasifican en dos grandes grupos; los virus del viejo mundo (Europa, Asia y África) y los virus del nuevo mundo (America). Los begomovirus del nuevo mundo tienen un genoma bipartita, mientras que los begomovirus del viejo mundo son de genoma bipartita y monopartita (Fauquet et al., 2003).

Los begomovirus se han convertido en una amenaza importante en la producción de diferentes cultivos a nivel mundial. Algunos de los efectos causados por estos fitopatógenos son devastadores, debido a la alta incidencia y severidad de la enfermedad que ellos provocan, constituyendo un serio riesgo para la agricultura, particularmente en zonas tropicales y subtropicales de todo el mundo (Morales y Anderson, 2001; Varma y Malathi, 2003). En América, los begomovirus están ampliamente distribuidos, se estima que alrededor de cinco millones de hectáreas en 20 países se ven afectadas por más de 30 geminivirus distintos (Morales y Anderson, 2001). Los geminivirus causan grandes pérdidas que fluctúan entre el $40 \%$ y $100 \%$ de la producción total, por ejemplo, en Florida (USA) el virus del jaspeado del tomate (Tomato mottle virus, ToMoV) produjo pérdidas sobre los 125 millones de dólares (Simone et al., 1990).

El tomate es el cuarto cultivo hortícola con mayor superficie en Chile y es la principal hortaliza en el valle de Azapa, Región de Arica y Parinacota (Chile), se cultiva durante todo el año y abarca una área de 685 ha, equivalente al $13 \%$ de la superficie nacional dedicada a este cultivo (Sepúlveda, 2011; Flaño Ipinga, 2012).

1 Laboratorio de Biotecnología Vegetal, Fac. Cs. Agronómicas, Universidad de Tarapacá. Arica, Chile. General Velásquez 1175, Casilla 6-D. Arica, Chile.

2 Laboratorio de Virología, Depto. Ingeniería Genética, Cinvestav Unidad-Irapuato. Gto., México. Km 9,6 Libramiento norte, carretera Irapuato-León. CP 36821. Irapuato, Gto, México.

* Autor por correspondencia: whuanca@uta.cl 
Debido a los cambios de las condiciones climáticas que se han producido en los últimos años en el valle de Azapa, se ha favorecido la dispersión y desarrollo de diversas enfermedades. Es así como en el año 2007 se produjo una considerable pérdida, del orden del $50 \%$, en la producción de tomate por causa de enfermedades de origen viral (Sepúlveda, 2011).

Los métodos de identificación de virus más utilizados en esta región se basan en la morfología y propiedades bioquímicas; sin embargo, técnicas basadas en biología molecular y secuenciación de ADN han demostrado ser los métodos más eficientes, confiables y precisos para la detección e identificación de virus (Rojas et al., 1993; Rosales et al., 2011). El objetivo del presente trabajo fue la detección molecular e identificación genética de begomovirus asociado a la enfermedad que afecta al cultivo del tomate en el valle de Azapa.

\section{Materiales y Métodos}

Se colectaron 20 muestras de tomate de la variedad Naomi cultivados al aire libre en el campo experimental de la Facultad de Ciencias Agronómicas de la Universidad de Tarapacá, Campus Azapa. Las muestras fueron tomadas de plantas que mostraban síntomas similares a los causados por geminivirus, se observaron diversos grados de desarrollo de mosaicos, encrespamiento, acopamiento de las hojas y aclaramiento o amarillamiento de las venas de las hojas. Como control negativo se utilizaron muestras de tomate libre de virus germinadas en placa y crecidas en cámara de crecimiento. Se aisló DNA genómico (DNAg) de cada muestra de acuerdo al protocolo reportado por Doyle y Doyle (1990). La detección molecular se realizó mediante la técnica de PCR. Los iniciadores utilizados fueron el PAR1c496 y PAL1v1978 (Rojas et al., 1993), los cuales generan un producto de PCR de aproximadamente $1100 \mathrm{pb}$. La secuencia amplificada incluye aproximadamente 690 pb del gen Rep, 300 pb de la región intergénica (IR) y 120 pb de la región 5' gen de la proteína de la cápside (CP) del componente A. Los productos de PCR fueron secuenciados por Biogenetics S.A. y la comparación con otras secuencias de begomovirus fue realizada utilizando el análisis tipo BLASTn (http://blast.ncbi.nlm.nih.gov/Blast.cgi). El análisis filogético fue realizado mediante un alineamiento de secuencias multiples, a través del método UPGMA y utilizando el programa MacVector 12.5.1. La confianza estadística de cada nodo fue estimada con 2.000 réplicas bootstrap.

\section{Resultados y Discusión}

La presencia de begomovirus fue confirmada molecularmente por análisis de PCR en todas las muestras colectadas que presentaron síntomas similares a los causados por geminivirus.

El producto de PCR obtenido fue clonado y dos clonas fueron secuenciadas. Se obtuvo una secuencia de $1121 \mathrm{pb}$, la cual fue idéntica en ambas clonas, dicha secuencia fue analizada y depositada en la base de datos del GenBank.

Para analizar la relación que existe entre la secuencia obtenida en este trabajo con begomivirus ya descritos, se realizó un análisis tipo BLASTn, el cual muestra que hay regiones que presentan una identidad a nivel nucleotídico del $97 \%-98 \%$ con el DNA de aislados del Tomato yellow vein streak virus (U79998.1, EF417915.1, GQ387369.1), seguido de un 88\%-89\% de identidad con el Tomato yellow vein streak virus (EF459696.1), Tomato yellow vein streak gemenivirus (AY829113.1) y con el Tomato golden vein virus (DQ346650.1, DQ346649.1, AY751742.1).

Un análisis filogenético basado en un alineamiento de secuencias múltiples fue realizado utilizando la secuencia reportada en este trabajo y secuencias de diferentes begomovirus como el Tomato yellow vein streak virus isolates G-22 (ToY-22, EF459696.1), Tomato yellow vein streak virus isolates T06 (ToYT06, GQ387369.1), Tomato rugose mosaic virus (ToRMV, NC_002555.1), Tomato golden mosaic virus (TGMV, NC_001507.1), Tomato chlorotic mottle virus (ToCMV, NC_003664.1), Pepper Golden Mosaic Virus (PepGMV, NC_004101.1), Leonurus mosaic virus (LeMV, U92532.1), Chino del tomate virus (CTV, NC_003830.1), Pepper Husteco Yellow Vein Virus (PHYVV, NC_001359.1), Sida golden mosaic virus (SiGMV, NC_002046.1), Abutilon mosaic virus (AbMV, X15983.2) y Bean golden mosaci virus (BGMV, NC_004042.1), Figura 1.

La secuencia reportada en este trabajo muestra baja variabilidad genética con los aislados de ToYSMV provenientes de Argentina y Brasil, con identidades del $95,6 \%$ y $88,0 \%$, respectivamente. El porcentaje de identidad a nivel de secuencia con otros grupos de begomovirus fue igual o menor del $70 \%$. Basados en estos antecedentes y de acuerdo con el International Committee on Taxonomy of Viruses (ICTV-2008, ente recomendado para la 


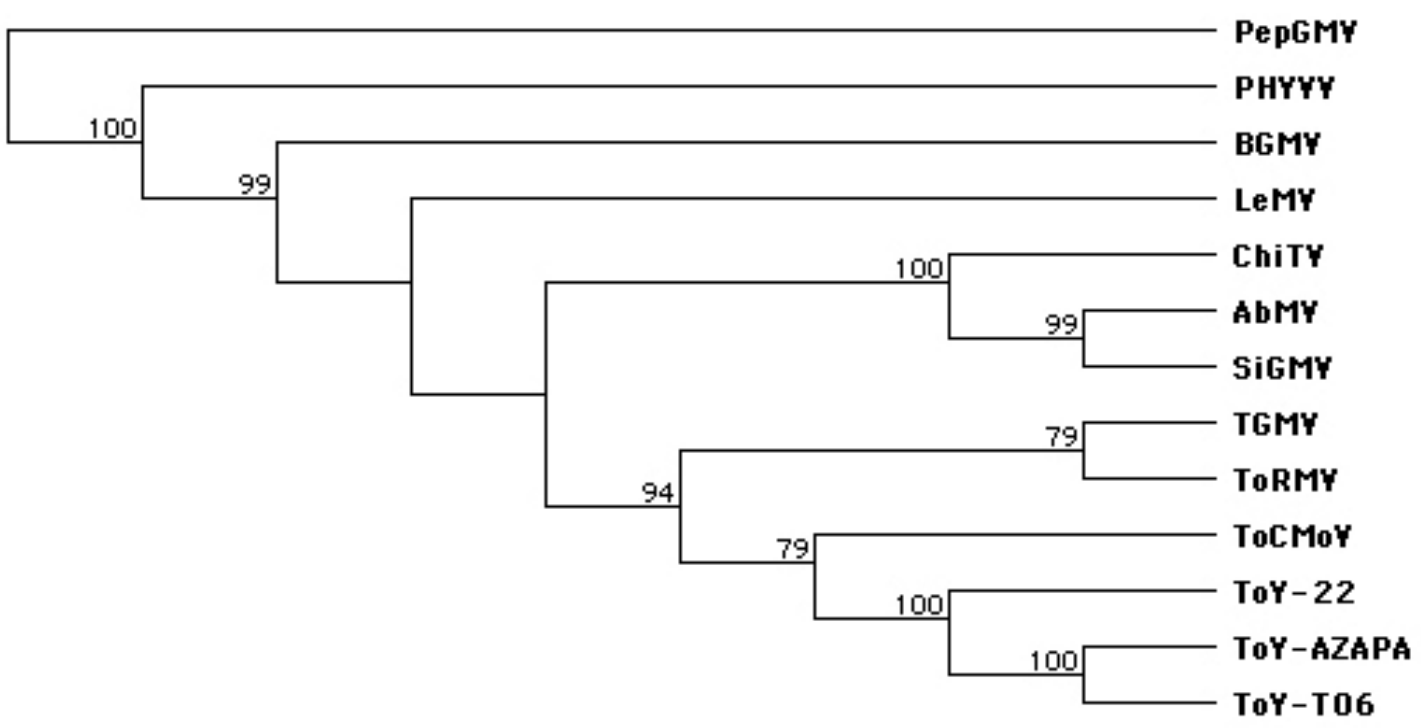

Figura 1. Árbol filogenético de la secuencia del ToY-Azapa reportada en este trabajo. Los valores de bootstrap (2.000 réplicas) están indicadas en cada nodo.

clasificación de begomovirus (Fauquet et al., 2008), los begomovirus identificados en el valle de Azapa fueron considerados como miembros del grupo de los ToYSMV identificados en Argentina y Brasil. Este es el primer reporte de la identificación genética de un begomovirus, presente en la región de Arica y Parinacota (Chile).

En los últimos años se ha registrado un aumento considerable en la identificación de nuevas especies de begomovirus del nuevo mundo que infectan al tomate (Morales y Anderson, 2001). Este inesperado aumento en el número de especies es atribuido a la introducción y a la eficiente capacidad de diseminación de la mosquita blanca del biotipo-B (Colariccio et al., 2007). Análisis de recombinación indican que nuevas especies de begomovirus están emergiendo en algunas zonas de Brasil y que dicha población se encuentra aún en formación (InoueNagata et al., 2006). En el valle de Azapa, los primeros reportes de la presencia de begomovirus en tomate fueron a partir del año 2006 (Sepúlveda,
2001), esto posiblemente debido a poblaciones de mosquitas blancas que migraron desde Argentina o Brasil. Es necesario determinar la presencia de este virus en otros valles del norte de Chile.

La detección temprana, rápida y precisa de begomovirus que afectan al tomate contribuirá para diseñar estrategias fitosanitarias que ayuden a evitar la rápida diseminación de la enfermedad y a combatir a estos patógenos. Además, permitirá dar respuesta oportuna a los agricultores evitando el consumo de tiempo que representan las pruebas bioquímicas, facilitando, de esta manera, la aplicación de medidas cuarentenarias por parte de la entidad que resguarda la sanidad vegetal en Chile.

\section{Agradecimientos}

Los autores expresan su agradecimiento al Gobierno Regional de Arica y Parinacota y a UTA-MECESUP2 por el financiamiento de esta investigación. 


\section{Literatura Citada}

Colariccio, A.; Eiras, M.; Chaves, A.L.R.; Bergmann, J.C.; Zerbini, F.M.; Harakava, R. y Chagas, C.M.

2007. Tomato yellow vein streak virus, a new begomovirus on tomato from brazil: complete dna-a sequence and some molecular and biological features. Journal of Plant Pathology, 89: 385-390.

Doyle y Doyle.

1990. Isolation of DNA from small amounts of plant tisúes. BRL Focus, 12: 13-15.

Fauquet, C.M.; Bisaro, D.M.; Briddon, R.W.; Brown, J.K., Harrison, B.D.; Rybicki, E.P.; Stenger, D.C. y Stanley, J.

2003. Revision of taxonomic criteria for species demarcation in the family Geminiviridae, and an updated list of begomovirus species. Archives of Virology, 148: 405-421.

Fauquet, C.M.; Briddon, R.W.; Brown, J.K.; Moriones, E.; Stanley, J.; Zerbini, M. y Zhou, X.

2008. Geminivirus strain demarcation and nomenclature. Archives of Virology, 153: 783-821.

Flaño Ipinza, A.

2012. Situación del tomate para consumo fresco. Oficina de Estudios y Políticas Agrarias (ODEPA).

Inoue-Nagata, A.K.; Martin, D.P.; Boiteux, L.S.; Giordano, L.B.; Bezerra, I.C. y de Ávila, A.C.

2006. New species emergence via recombination among isolates of the Brazilian tomato infecting Begomovirus complex. Pesquisa Agropecuária Brasileira, 41: 13291332.

Morales, F.J. y Anderson, P.K.

2001. The emergence and dissemination of whitefly-transmitted geminiviruses in Latin America. Archives of Virology, 146: 415-441.

Rojas, M.R.; Gilbertson, R.L.; Russell, D.R. y Maxwell, D.P. 1993. Use of degenerate primers in the polymerase chain reaction to detect whitefly-transmitted geminiviruses. Plant Disease, 77: 340-347.

Rosales, M.; Medina, C.; Mora, R. y Rojas, C.

2011. Prospección y diagnóstico de virus en tomate. Instituto de investigaciones agropecuarias. Boletin INIA No 224 : 21-31.

Sepúlveda, $\mathrm{P}$.

2011. Virus trasmitidos por insectos vectores en tomate en la región de Arica y Parinacota: situación actual y manejo. Instituto de investigaciones agropecuarias. Boletin INIA No 224: 9-11.

Simone, G.W.; Brown, J.K.; Hiebert, E. y Cullen, R.C. 1990. Geminiviruses associated with epidemics in Florida tomatoes and pepper. Phytopathology, 80: 1063-1070.

Varma, A. y Malathi, V.G.

2003. Emerging geminivirus problems: A serious threat to crop production. Annual Apply Biology, 142: 145-64. 